\title{
Mycorrhization of micropropagated mature wild cherry (Prunus avium L.) and common ash (Fraxinus excelsior L.)
}

\author{
Paulo E. Lovato, Neil Hammatt, Vivienne Gianinazzi-Pearson and Silvio Gianinazzi
}

Lovato, P.E.', Hammatt, N. ${ }^{2}$, Gianinazzi-Pearson, V.' \& Gianinazzi, S.' 1994. Mycorrhization of micropropagated mature wild cherry (Prunus avium L.) and common ash (Fraxinus excelsior L.). Agricultural Science in Finland 3: 297302. ('Laboratoire de Phytoparasitologie INRA-CNRS, Station de Génétique et d'Amélioration des Plantes, INRA, BV 1540, 21034 Dijon, France; ${ }^{2}$ Horticulture Research International, East Malling, West Malling, Kent ME19 6BJ, United Kingdom. Present address: Paulo E. Lovato, Universidade Federal de Santa Catarina, Florianópolis, Brazil.)

\begin{abstract}
Micropropagated plants of common ash and wild cherry were inoculated with arbuscular mycorrhizal fungi during a 20-day weaning period, after which they were transferred to two different substrata supplemented with slow-release fertilizer. After a 13-week growth period, the stem height and diameter of the ash plants which had been inoculated with Glomus intraradices were three times greater than those of uninoculated control plants. Increasing the peat content of the substratum improved growth of ash. Four weeks after being transferred to pots, shoots of wild cherry inoculated with $G$. intraradices or $G$. deserticola were taller and stems thicker than those of control plants, whereas those inoculated with Gigaspora rosea had shorter shoots and thinner stems than the controls. These beneficial effects of fungal inoculation on plant development disappeared after 13 weeks. Increasing the peat content, but not the level of fertiliser of the substratum, improved growth of both inoculated and uninoculated wild cherry.
\end{abstract}

Key words: substratum, Glomus intraradices, Glomus deserticola, Gigaspora ro$s e a$, arbuscular mycorrhizas, weaning, tree, forestry

\section{Introduction}

Micropropagation is an important method for rapidly propagating many plants. Indeed, in some trees, including common ash (Fraxinus excelsior L.), micropropagation is the only published reliable means of clonal propagation (AнUJA 1993). Micropropagated plants are usually transferred to disinfested soil or artificial substrata. Thus, their access to mycorrhizal fungi is reduced or eliminated. Such fungi have beneficial effects on plant development, especially through improved phosphorus $(\mathrm{P})$ nutrition, increased resistance to path- ogens and better root development (GIANINAZZI et al. 1990). The absence of symbiosis may account for the poor development of ash plants, even in heavily fertilised soils (Douds and Chaney 1986, Le TACON and Bouchard 1988).

Inoculation with mycorrhizal fungi can enhance the growth of micropropagated plants, as demonstrated by Pons et al. (1983) and RavolaniRINA et al. (1989), who succeeded in obtaining mycorrhizal infection of wild cherry and vine microplants under axenic conditions. The time of inoculation of microplants has, however, been proved important. Pineapple (GuILLEmIN et al. 1992), oil 
palm (Blal et al. 1990) and vine (RAVOLANIRINA et al. 1989) microplants, for example, were more successfully established if they were inoculated with mycorrhizal fungi at the beginning of the weaning period, whilst avocado microplants grew better if inoculated after a period of weaning in an uninoculated substratum (AzCón-AGUILAR et al. 1992).

The current experiments were carried out to assess whether micropropagated ash and wild cherry would benefit from inoculation with mycorrhizal fungi during the weaning phase. The performance of substratum-fertiliser combinations, similar to those used in nurseries, in the production of mycorrhizal micropropagated wild cherry was also assessed.

\section{Material and methods}

\section{Plant material}

Common ash (Fraxinus excelsior L.) clone 71 and wild cherry (Prunus avium L.) cv. F12/1 were obtained by micropropagation using previously published techniques (HammatT 1994, HammatT and GRANT 1993).

\section{Weaning and fungal inoculation}

Micropropagated plants with one or two root primordia were transferred to seed trays containing a 2:1:1 mixture of clay loam, perlite and grit. For mycorrhizal plants, the inoculum consisted of roots of leek infected with Glomus intraradices Schenck \& Smith (isolate LPA 8), or sievings of soil containing Glomus deserticola Trappe, Bloss \& Menge (LPA 27) or Gigaspora rosea Nicolson \& Schenck (LPA 23). Plants were weaned for 20 days in a tall lid propagator $\left(\right.$ Maxi-Serre ${ }^{R}$, Bouillard Frères, Saint Germain-en-Plain, France) (12h. per day, $19-22^{\circ} \mathrm{C}, 220 \mathrm{mE} . \mathrm{cm}^{-2} \cdot \mathrm{s}^{-1}, 70 \%$ r.h.). After this period, root samples were taken to check for the presence of mycorrhizal infection after clearing with $\mathrm{KOH}$ and staining with trypan blue (Phillips and HaYman 1970).

\section{Growth in greenhouse}

After weaning, plants were transferred to pots $\left(2 \mathrm{dm}^{3}\right)$ in a greenhouse (July-October, $19-24^{\circ} \mathrm{C}$, light supplemented to $16 \mathrm{~h}$ day). Two substrata were tested; substratum 1, which consisted of $40 \%$ (v/v) clay loam, $20 \%$ peat, $20 \%$ wood chips and $20 \%$ grit; and substratum 2, which consisted of $20 \%$ clay loam, $40 \%$ peat, $20 \%$ wood chips and $20 \%$ grit. The substrata were steam disinfected and received a mixture of $\mathrm{CaCO}_{3}$ and $\mathrm{MgCO}_{3}$ (3:2) corresponding to $1.5 \mathrm{~kg} \cdot \mathrm{m}^{-3}$, and $\mathrm{NH}_{4} \mathrm{NO}_{3}$ corresponding to $150 \mathrm{~g} \cdot \mathrm{m}^{-3}$. Two levels of fertilisation were used, corresponding to $2 \mathrm{~kg} \cdot \mathrm{m}^{-3}$ (Fert. 1) or to $4 \mathrm{~kg} \cdot \mathrm{m}^{-3}$ (Fert. 2) of a slow release fertiliser $\left(\right.$ Osmocote $^{\mathrm{R}}$, Sierra Chemical Europe, Herleen, The Netherlands) with a final composition of NPK of 16:9:12, in a 1:1 mixture of 3 to 4 month and 8 to 9 -month release time types. Treatments were arranged in randomized blocks with five replicates.

\section{Data analysis}

Data were analysed with the Stat-ITCF Program and differences were calculated by the NewmanKeuls test at $\mathrm{P}<0.05$.

\section{Results}

\section{Common Ash}

Common ash plants were inoculated with Glomus intraradices only and fertilised at the Fert. 1 level. During weaning, roots of inoculated ash plants were well infected by the mycorrhizal fungus (about $70 \%$ of the root cortex), but development of the mycorrhizal plants was depressed. However, 4,9 , and 13 weeks after transfer to substrata 1 and 2, stems of inoculated plants were significantly taller and thicker $(\mathrm{P} \leq 0.05)$ than those of the control plants (Fig. 1 a, b). At 9 weeks, there were significant differences in stem height between the substrata $(P \leq 0.05)$. Overall, there was a tendency for better growth of uninoculated plants in substratum $2(\mathrm{P} \leq 0.1)$, which was richer in peat. 

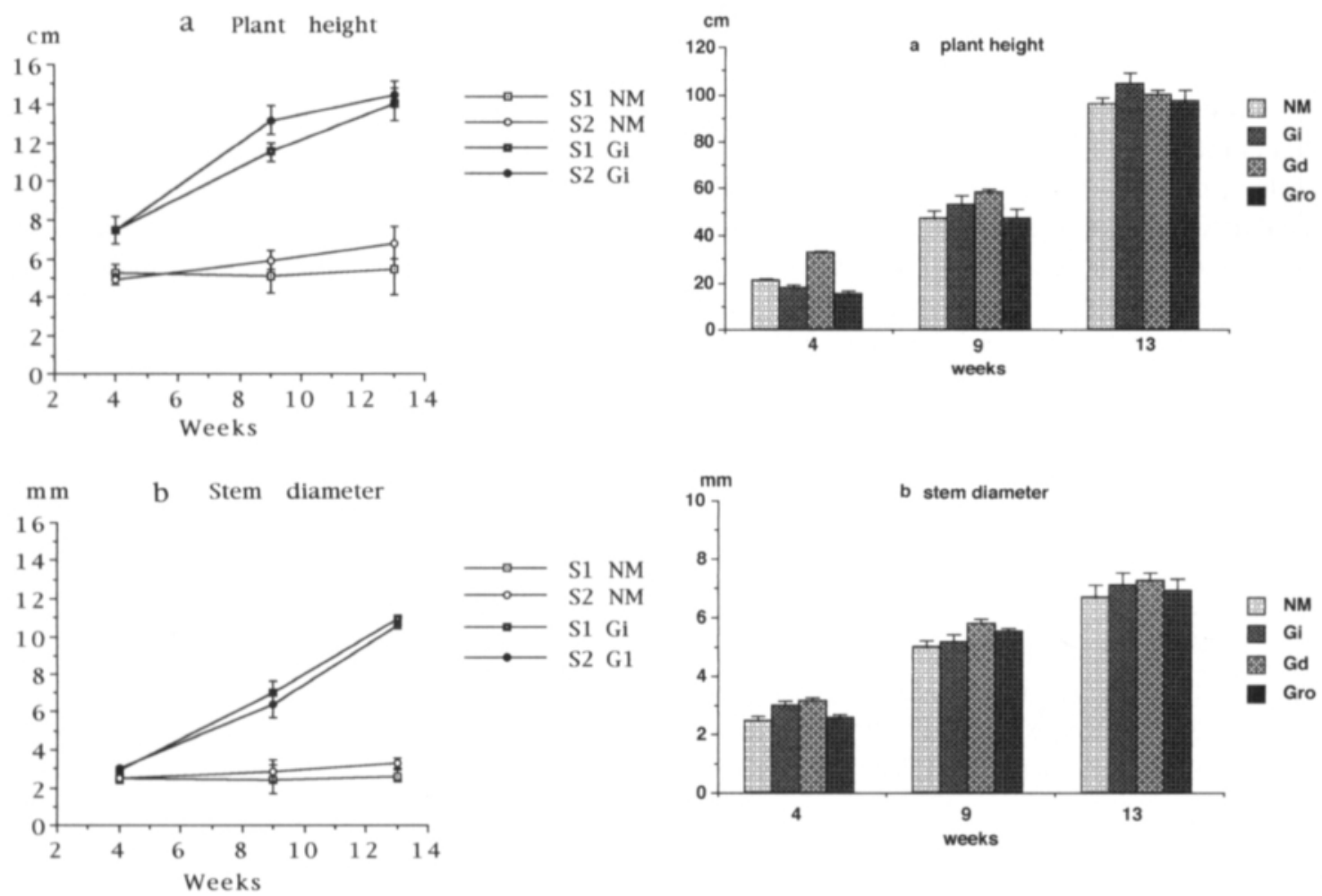

Fig. 1. Plant height (a) and stem diameter (b) of common ash plants non inoculated (NM) or inoculated with Glomus intraradices (Gi) and growing in substrata with $20 \%$ peat (S1) or with $40 \%$ peat (S2) in a greenhouse. Mean of five replicates. Bars represent standard errors of the mean.

\section{Wild Cherry}

\section{Comparison of fungi}

Plants were inoculated with $G$. intraradices, $G$. deserticola or $G$. rosea, and transferred only to substratum 1 with the lower fertiliser level (Fert. 1). At the end of the weaning period, roots were well infected by the Glomus species, showing about $75 \%$ of the cortex occupied by mycorrhizal fungal structures, whilst the infection rate was about $45 \%$ with $G$. rosea. Shoot growth was better with the Glomus species than with the control plants, whilst $G$. rosea had a depressive effect on plant height. After four weeks in substratum 1, there were some differences $(\mathrm{P} \leq 0.05)$ between

fungal treatments, with a positive effect of $G$. deserticola. At 9 weeks, however, the differences diminished, and plant growth was similar in all treatments at 13 weeks (Fig $2 \mathrm{a}, \mathrm{b}$ ).

\section{Comparison of substrata and fertilisers}

The effect of substrata was evaluated at the lower fertiliser level, using control plants and plants inoculated with $G$. intraradices or $G$. deserticola. The early beneficial effects of inoculation with G. deserticola were observed again, and, as in the first experiment, they disappeared with time, since at 9 and 13 weeks, only the type of substratum had significant effects on growth ( $\mathrm{P} \leq 0.05)$. At 13 weeks, plants in substratum 1 were $100 \mathrm{~cm}$ 
in height, with a stem diameter of $7.0 \mathrm{~mm}$, and those in substratum 2 were $107 \mathrm{~cm}$ in height, with a stem diameter of $7.9 \mathrm{~mm}$ [LSD (5\%) were $6.3 \mathrm{~cm}$ for height and $0.75 \mathrm{~mm}$ for diameter].

In a third experiment, interactions between inoculation, substratum and fertiliser level were evaluated on wild cherry plants inoculated with $G$. intraradices. Plant growth was affected by the substratum $(\mathrm{P} \leq 0.05)$, growing better in the medium with a higher peat content, but not by fertiliser or inoculation with the mycorrhizal fungus.

\section{Discussion}

Micropropagated ash proved to be highly responsive to mycorrhizal inoculation, as demonstrated previously with conventionally propagated plants of other Fraxinus spp. (CLARK 1969, DoudS and Chaney 1986, Ponder 1984). The latter studies used substrata containing at least one-third soil and no peat. In the current experiments, however, we achieved beneficial mycorrhizal effects using a substratum with a high level $(60 \%)$ of inert or low density materials which are not normally conducive to mycorrhiza formation (RAVOLANIRINA 1990, WoOD 1991). Our results using relatively high $\mathrm{P}$ fertilisation, equivalent to at least $360 \mathrm{~kg} \mathrm{P} \mathrm{ha}^{-1}$, are similar to those of Douds and CHANEY (1986) and LE TACON and Bouchard (1988), who also showed mycorrhizal effects with Fraxinus spp. in the presence of high soil P.

Although we did not observe a positive mycorrhizal effect with the clone of Prunus avium used, the mycorrhizal dependence of this woody plant has been demonstrated with other species including peach (LAMBERT et al. 1979) and Prunus cerasifera (FoRTUNA et al. 1992); the latter authors also recommended early inoculation with rapidly infecting fungal strains. Better results with wild cherry might be achieved using other fungal strains, since mycorrhizal benefits depend on the fungus used, as observed for Prunus dulcis (ROLDAN-FAJARDO et al. 1982) or for the almond x peach clone rootstock GF677 (ESTAÚn et al. 1994). The latter authors obtained lower root/shoot (R/S) ratios with mycorrhizal fungal inoculation whatever the fungus used, showing that irrespective of the growth of aerial part, inoculated plants had an underground organ more efficient in the promotion of growth. The poor response to $G$. rosea may be due to the fungus needing longer to infect wild cherry roots. The results also suggest that micropropagated wild cherry should be grown in a substratum with a high proportion of lowdensity materials, such as peat and wood chips. In fact, it should be stressed that, under these conditions, the clones of Prunus used attained two to three times the size of plants reported in the literature for a comparable period of growth (ESTAÚN et al. 1994). Furthermore, it took the plants only a few months to achieve the height usually obtained for wild cherry seedlings after two years in nurseries. However, the fertilizer dose should be re-evaluated in order to obtain similar development at lower cost; this might be possible with the introduction of efficient mycorrhizal fungi in the substratum.

The ash and wild cherry plants produced in our study will be transferred to the field to assess whether establishment and disease resistance are improved in mycorrhizal plants. It will also be necessary to evaluate the agronomic and economic benefits of mycorrhization, especially the scope for reducing fertilisation requirements. This will require further screening and comparisons of fungal strains to select those best adapted to each species.

Acknowledgements. The authors thank Dr. C. Azcón-Aguilar of the Zaidin Experimental Station, Spain for providing the Glomus deserticola inoculum and Pascal Perney for technical assistance. P.E.L. has a scholarship from the CNPq-RHAE Programme from the Brazilian Ministry of Science and Technology. N.H. is supported by the UK Ministry of Agriculture, Fisheries and Food and the Agricultural Food Research Council. This collaborative work was partly supported by COST ACTIONS 87 and 8.10 in the BRIDGE Programme. 


\section{References}

AhujA, M.R. 1993. Biotechnology and clonal forestry. In: Ahuja, M.R. \& Libby, W.J. (eds.). Clonal Forestry I: Genetics and Biotechnology. Springer-Verlag, BerlinHeidelberg, p. 135-144.

Azcón-Aguilar, C., Barceló, A., Vidal, M.T. \& dE LA VIÑA, G. 1992. Further studies on the influence of mycorrhizae on growth and development of micropropagated avocado plants. Agronomie 12: 837-840.

Blal, B., Morel, C., Gianinazzi-Pearson, V., Fardeau, J.C. \& GianinazZI, S. 1990. Influence of vesiculararbuscular mycorrhizae on phosphate fertilizer efficiency in two tropical acid soils planted with micropropagated oil palm (Elaeis guineensis jacq.). Biology and Fertility of Soils 9: 43-48.

Clark, F.B. 1969. Endotrophic mycorrhizal infection of tree seedlings with Endogone spores. Forest Science 15: 134-137.

Douds, D.D. \& ChaneY, W.R. 1986. The effect of high nutrient addition upon seasonal patterns of mycorrhizal development, host growth, and root phosphorous and carbohydrate content in Fraxinus pennsylvanica Marsh. New Phytologist 103: 91-106.

Fortuna, P., Citernesi, A., Morini, S., Giovanetti, M. \& LORETI, F. 1992. Infectivity and effectiveness of different species of arbuscular mycorrhizal fungi in micropropagated plants of $\mathrm{Mr} \mathrm{S} 2 / 5$ plum rootstock. Agronomie 12: 825-829.

Gianinazzi, S., Gianinazzi-Pearson, V. \& Trouvelot, A. 1990. Potentialities and procedures for the use of endomycorrhizas with emphasis on high value crops. In: Whips, J.M. \& Lumsden, B. (eds.). Biotechnology of fungi for improving plant growth. Cambridge University Press, Cambridge. p. 41-54.

Guillemin, J.P., Gianinazzi, S. \& Trouvelot, A. 1992. Screening of VA endomycorrhizal fungi for establishment of micropropagated plants. Agronomie 12: 831836.

Hammatт, N. 1994. Shoot initiation in the leaflet axils of compound leaves from micropropagated shoots of juvenile and mature common ash (Fraxinus excelsior L.). Journal of Experimental Botany (in press).

- \& Grant, N.J. 1993. Apparent rejuvenation of mature wild cherry (Prunus avium L.) during micropropagation. Journal of Plant Physiology 141: 341-346.
Lambert, D.H., Stouffer, R.F. \& Cole JR., H. 1979. Stunting of peach seedlings following soil fumigation. Journal of the American Society of Horticultural Science 104: 433-435.

Le Tacon, F. \& Bouchard, D. 1988. Growth of Fraxinus excelsior and Acer pseudoplatanus seedlings mycorrhizal with Glomus mosseae after five years on a routine reforestation site. Second European Symposium on Mycorrhizas, Prague. p. 62-63.

PhILliPS, J.M. \& HAYMAN, D.S. 1970. Improved procedures for clearing roots and staining parasitic and vesicular-arbuscular mycorrhizal fungi for rapid assessment of infection. Transactions of the British Mycological Society 55: 158-160.

PONDER, F. Jr. 1984. Growth and mycorrhizal development of potted white ash and black walnut fertilized by two methods. Canadian Journal of Botany 62: 509 512.

Pons, F., Gianinazzi-Pearson, V., Gianinazzi, S. \& NAVATEL, J.C. 1983. Studies on VA mycorrhizae in vitro: mycorrhizal synthesis of axenically propagated wild cherry (Prunus avium L.) plants. Plant and Soil 71: 217-221.

RAVOLANIRINA, 1990. L'endomycorhization VA des plantes ligneuses (vigne, pommier et poirier) micropropagées: Techniques d'inoculation, analyse de la morphogenèse racinaire et approches biochimique et immunologique. PhD Thesis. Université de Bourgogne.

-, Gianinazzi, S., Trouvelot, A. \& Carré, M. 1989. Production of endomycorrhizal explants of micropropagated grapevine rootstocks. Agriculture Ecosystems and Environment 29: 323-327.

Roldan-Fajardo, B.E., Barea, J.M., OCAMPO, J.A. \& AzCon-Aguil.ar, C. 1982. The effect of season on VA mycorrhiza of the almond tree and of phosphate fertilization and species of endophyte on its mycorrhizal dependency. Plant and Soil 68: 361-367.

WooD, T. 1991. VA mycorrhizal fungi: challenges for commercialization. In: Arora, D.K., Rai, B., Mukerji, K.G. \& Knudsen, G.R. (eds.). Handbook of Applied Mycology. Marcel Dekker, Inc., p. 823-846.

\section{Manuscript received January 1994}




\title{
SELOSTUS
}

\section{Mykorritsasiirrostus mikrolisätyllä imeläkirsikalla ja saarnella}

\author{
Paulo Lovato' ${ }^{1}$, Neil HammatT ${ }^{2}$, Vivienne Gianinazzi-Pearson ${ }^{1}$ ja Silvio Gianinazzi ${ }^{1}$
}

'Laboratoire de Phytoparasitologie INRA-CNRS, Ranska ja ${ }^{2}$ Horticultural Research International, Iso-Britannia

Imeläkirsikan (Prunus avium L.) ja saarnen (Fraxinus excelsior L.) mikrolisättyihin pikkutaimiin siirrostettiin arbuskelimykorritsasieniä karaistumisvaiheen aikana. Karaistuneet taimet siirrettiin kahdelle erityyppiselle alustalle, jotka oli lannoitettu hallitusti liukenevalla lannoitteella.

Glomus intraradices -sienellä siirrostetut saarnen taimet olivat kolmentoista viikon kuluttua korkeudeltaan ja halkaisijaltaan kolminkertaisia siirrostamattomiin taimiin verrattuna. Saarnen kasvu parani kasvualustan turvepitoisuutta nostettaessa.

$G$. intraradices - tai $G$. deserticola -sienillä siirrostetut imeläkirsikan taimet olivat neljän viikon kasvatusajan jälkeen isompia ja halkaisijaltaan paksumpia kuin siirrostamattomat taimet. Sen sijaan Gigaspora rosea-sienellä siirrostetuilla taimilla oli lyhyemmät juuret ja laihemmat versot kuin siirrostamattomilla taimilla. Imeläkirsikalla mykorritsasiirrostuksen myönteiset vaikutukset olivat kuitenkin hävinneet kolmentoista kasvatusviikon jälkeen. Sekä mykorritsasiirrostettujen että siirrostamattomien imeläkirsikan taimien kasvu parani, kun kasvualustan turvepitoisuutta nostettiin lannoitustasoa kuitenkaan muuttamatta. 